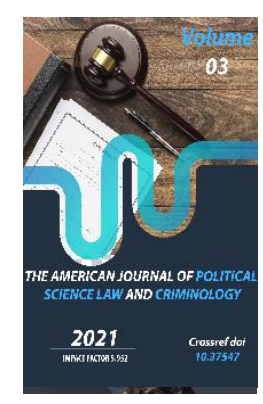

\title{
The Essence And Characteristics Of The Content Administrative Court Proceedings
}

\author{
Sh.I.Shayzakov \\ Independent Researcher, Lecturer, Junior Counselor Of Justice Academy Of The General \\ Prosecutor's Office Of The Republic Of Uzbekistan
}

Copyright: Original content from this work may be used under the terms of the creative commons attributes 4.0 licence.

\section{ABSTRACT}

The article deals with the analysis on the disputes arising from public legal relations, the basics of administrative proceedings, the theoretical features of the concepts of public legal relations, public legal dispute, administrative dispute, administrative proceedings, the views of scholars in this point and foreign experience.

\section{KEYWORDS}

Public legal relationship, public legal dispute, administrative dispute, administrative court proceeding.

\section{INTRODUCTION}

The administrative court process has its own characteristics with its variety and complexity. This is due to the fact that the powers (duties, responsibilities) of administrative bodies (government bodies, local executive bodies, citizens' self-government bodies) participating as one of the parties in administrative proceedings are determined by a wide range of legislation. 
In order to understand the concept of administrative proceedings, it is necessary to understand the essence of the concepts which are its basis "public legal relations", "public legal dispute", "administrative dispute" and "administrative court proceedings".

Obviously, the question arises as what do we understand by the essence of a legal dispute? When we talk about a legal conflict, it should be noted that the participants are expressed in the form of a certain mutual contradiction. A conflict from a legal point of view can serve as a starting point for a conflict. This is due to the fact that in some cases the dispute can be resolved by agreement of the parties and the dispute may not become a legal relationship [1].

\section{THE MAIN FINDINGS AND RESULTS}

An essential condition affecting the legal nature of the dispute is its content. In particular, disputes between citizens, such as inherited ones, are of a civil nature, and disputes between an administrative body and a citizen related to the refusal to register him as an individual entrepreneur have a public law content, or rather an administrative content. (administrative dispute).

The difference in the types of disputes depends not only on the subject participated in one of these disputes, but also on the nature of which is an important point of discussion.

N.M. Korkunov refers to the difference between administrative and civil justice, which deals with public legal disputes, and expresses it as the difference between public and private law [2].
So, if a private legal relationship (civil law, family, housing, etc.) is implemented through procedural relations, appear private law disputes; if the procedural relationship facilitates the implementation of administrative, financial, tax, budgetary, and other public substantive legal relationships, arises a public legal dispute. It means that a public legal dispute is a dispute whose content consists of issues arising from the public branches of law. For instance, a dispute involving issues of financial legislation can be called a financial public dispute; tax issues public tax dispute, administrative issues administrative dispute, etc. Certainly, administrative public disputes play a role in the procedural maintenance of material administrative relations. As scholars rightly point out, if the issue that constitutes the content of the dispute is administrative law this dispute has administrative feature.

As D.M.Chechot mentioned that, administrative bodies can have legal relations with citizens or organizations in different contexts: administrative, civil, land, financial, labor, and so on. In some cases administrative actions lead to not only administrative but also, other consequences (e.g., civil). In such cases, the dispute loses its administrative character [3].

Consequently, considering the comparative superiority of substantive legal relations over procedural relations designed to ensure the implementation of these relations, we can confirm that the material aspect that characterizes the difference between public law and private law disputes is a key factor in distinguishing these types of disputes. For instance, if an administrative body refuses a citizen to register the right of ownership to an 
apartment, both a civil dispute and an administrative dispute may arise. This means that a person must determine the nature and content of the dispute before filing application. If the administrative body refuses to register the right on procedural grounds, the court checks the legality of the actions of the body (its official) in resolving the administrative dispute in the administrative proceedings. If the rejection was made due to the absence of this right of the person, then the dispute is of a private legal nature and the person must immediately apply to the court in the form of a claim to resolve the private dispute. The key difference between public legal disputes and private disputes depends on the legal nature of the dispute. We agree with the attitude of the scientist E.V Khakhaleva [4] on the consideration of public legal disputes in the order of administrative proceedings, which are not civil law disputes, but procedural protective equipment that differ from civil disputes.

After the introduction in our country, the order of administrative proceedings and the establishment of a special order required the definition of the category "administrative case".

Lawyer V. Bolgova mentions that "public legal relations" are the most effective means of social relations regulated by the state through certain rules [5].

A. Miyagasheva states that public legal relations are the basis of state legal relations, and the types of legal relations is the unity of legal rights and obligations of legal entities, defined and protected by the state [6].

V.Nikolaenko maintains that "public legal relations" is aimed at developing scientific knowledge on the subject of regulation of administrative law and helps to identify the features and boundaries of private legal relations - [7].

There is some contradiction in the views of these scholars, and some views cannot be fully agreed on. This is because administrative law regulates the social relations that arise in the process of organization and implementation of public administration. Public legal relations include social relations between citizens and officials in the field of court case, in addition to the administrative court. In our opinion, "public legal relations" are social relations governed by the norms of public law.

S.E. Shindyapin, stating to the peculiarities of public legal relations, mentions the following: first, the subjects are not mutually equal in legal status; secondly, the existence of subjects with public legal status, the powers of state power; thirdly, on the basis of the principle of "subordination to authority", one party has only legal obligations and the other party has subjective rights; fourth, the powers of the subject of authority will have the status of an obligation; fifth, the individual acts as a required party, the official acts as an authorized person; sixth, that different forms of public associations can act as subjects [8].

Moreover, some scholars who have studied the problems of public legal relations mention the following as their peculiarities:

- The subjects of public legal relations are subordinated to the authorities and the parties do not have equal legal status;

- One of the authority (governing entity) has authority over another (managed 
entity) and may issue binding unilateral instructions to it;

- Legal relations, as a rule, arise regardless of the will of the controlled entity [9].

Additionally to these views, today as subjects of public-legal relations can be found individuals and legal entities, and on the other hand, not only government agencies, but also various subjects having powers of government.

Decentralization in democratic countries occurs not only within the system of state bodies, but also outside it. In particular, some state functions are transferred to nongovernmental organizations (civil society institutions). This leads to an expansion of the range of subjects under the authority of the authorities involved in public relations.

For instance, the legislation of the Republic of Uzbekistan provides for appeals to the administrative court against decisions, actions (inaction) of citizens' self-government bodies and their officials that do not comply with the law and violate the rights and legally protected interests of citizens or legal entities. Therefore, when a dispute arising from publiclegal relations is considered in an administrative court, the body of citizens 'selfgovernment appears as a subject with jurisdiction.

As to Y. Tikhomirov, a "public law dispute" is a public dispute that is considered by the competent state authorities in the procedural order established by law. Such disputes are considered public law if they involve issues related to areas of public law (constitutional, administrative, financial, tax, labor, etc.) [10].

Administrative cases are of a public nature and require consideration in a special procedural order. The peculiarity of public legal disputes is that the participants in this conflict are not legally equal. In particular, D.M. Zamyshlyaev points out that this is the inequality of the subjects of legal relations, that is, one of them is endowed with power functions, but also the peculiarity of the legal relationship, which led to the allocation of this special jurisdiction [26].

The concepts of "public dispute" and "administrative dispute" in many cases can be expressed as a whole or as part of the former. In particular, according to T.V. Peshkova, administrative and legal disputes include all disputes with the participation of executive authorities as one of the parties, as well as other bodies exercising state administration and their officials [12].

Yu.N. Starilov maintains that "administrative and legal disputes" are legal disputes between state bodies, local authorities, officials, on the one hand, and the subjective public rights of individuals and legal entities, on the other [13].

A.V. Glodina focuses on the concept of public legal disputes, describing it as disagreements between unequal subjects, such as the abovementioned scientists, on the one hand there is always an executive or other state body and an official in charge of public administration, as well as public rights and decisions, actions (inaction) of these persons, leading to violation of interests, regulatory legal acts and other public decisions and actions. At the same time, he points out that the presence of a public law dispute and its transfer to the court for consideration and resolution creates a legal phenomenon in the form of an "administrative case" [14]. 
We can consider that the opinions of the above scholars are similar to each other. Because, T.V Peshkova, Yu.N. Starilov, A.V Glodina also emphasizes the superiority of officials in administrative and public legal disputes over the other party, and that the disputes between them are related to administrative and public legal relations.

In our opinion, public rights of individuals or legal entities are the result of the development of illegal administrative rules by state bodies, local authorities, officials and other legal entities, or the emergence of a conflict of interest in public administration, which leads to legal conflicts.

Administrative legal dispute has a public legal character and is considered as a type of public legal dispute, and its purpose is to protect the violated rights and interests of citizens. Therefore, in our opinion, the concept of "administrative-legal dispute" should be considered as part of the concept of "publiclegal dispute" as well as, must be officials with having authority. In other cases, such disputes remain under the jurisdiction of a court other than an administrative court.

If we observe the legislation of foreign countries on public legal disputes, in Ukraine as public legal disputes - disputes over the appeal of individuals and legal entities against the decision, action or inaction of an authorized body; disputes over the admission of citizens to public service; disputes over the exercise of administrative powers between the subjects of authority, the powers transferred to a lower body or another body; disputes arising from the conclusion, execution, termination, cancellation or invalidation of administrative contracts; Disputes on the appeal of a subject authorized by the authorities in the manner prescribed by the Constitution and laws of Ukraine; disputes related to the election process or referendum; disputes between individuals and legal entities over the decision, action or inaction of the media provider to obtain the media; Disputes between individuals and legal entities over complaints about decisions, actions and inactions of the customer are recognized in the relations arising under the Law of Ukraine "On the specifics of the procurement of goods, works and services for the defense needs" [15].

As it can be seen from the legislation of this state that public legal disputes involve relations with administrative bodies arising from constitutional, electoral, administrative, contractual and other relations. Disputes arising as a result of non-fulfillment of obligations by administrative bodies or illegal performance of actions by an official, as well as disputes of a property nature, are considered by administrative courts. At the same time, we can see the existence of administrative bodies with the powers of government.

Based on the above, we can list the following general features of the concept of "public legal dispute":

a) Public legal disputes cover issues related to the field of public law;

b) In public legal disputes, one of the parties to the relationship is represented by a subject with authority, and the parties to the relationship are not equal;

c) A special procedure for resolving public legal disputes will be introduced; 
d) Public legal dispute occurs on the application of substantive and procedural law, which determines the rights and obligations of the subjects, their behavior;

e) Public legal disputes appear on the basis of decisions made by public authorities and actions (inaction) of officials, regulations, other public decisions and actions.

N.Yu. Khamaneva defines the concept of "administrative legal dispute" as a expression of a legal dispute, noting that such a dispute occurs in the management process, the subjects have a special status and the dispute is resolved in a special order [16].

Some legal scolars focus on the inconsistency in the concept of administrative dispute over the application of substantive law that defines the behavior, rights, and obligations of various subjects [23].

According to E.B. Luparev, the main difference between administrative legal disputes and other legal disputes is that it has a special subject structure and object. A special subject of administrative legal disputes is a person or organization with the powers of public administration. The object of administrative legal disputes is the protection of administrative rights, legitimate interests and the order of implementation of public administration obligations. The subject of administrative legal disputes is the subject of the exercise of subjective management rights and obligations of the body or person to whom the powers of the state are delegated, the interests of unsecured public administration. The fact that public rights, interests and obligations have a managerial character is one of the criteria that distinguish administrative legal disputes from other legal disputes [18].

According to Yu.M. Kozlov, administrative legal disputes arise when the rights and legitimate interests of one of the participants of a specific administrative-legal relationship are violated by another or in some way adverse events [19].

According to E.Khojiev, G.Khakimov, an administrative legal dispute is a dispute over the rights and obligations of the subjects of administrative law [20].

The estimations of these scholars cover ideas that complement each other in content. In their opinion, administrative and legal disputes are administrative disputes that arise as a result of the establishment or cancellation of tasks assigned to them by law in the field of public administration by public administration bodies, other bodies authorized to carry out administrative and legal activities, citizens' self-government bodies and their officials.

The emergence of administrative legal disputes is based on the legal facts that create, change and terminate the administrative legal relationship.

Based on the above considerations, the following conclusions can be drawn on administrative legal disputes:

a) Administrative legal disputes - affect the rights and obligations of the subjects of administrative law, i.e. the violation of the rights and interests of citizens, legal entities, including foreign legal entities, as a result of the exercise of these procedural rights and obligations;

b) There is a disappointment of the subjects of administrative legal relations with the 
decision of the person authorized to manage, that is, disputes arise as a result of decisions of these persons that do not comply with the law and violate the rights and legally protected interests of citizens or legal entities; (For example, a dispute arising from a violation of the rights and interests of the LLC as a result of the annulment of part of the decision of the governor on the allocation of land on the basis of rent and common property on the basis of a prosecutor's protest.)

c) Administrative legal disputes depend on the action (inaction) of a state body or official or an executive body. For instance, the requirements of the law established by the permanent registration of a citizen, the interests of the citizen are violated and a conflict arises as a result of the actions of officials of the Department of Migration and Citizenship of the Coordination Department of Internal Affairs.

In this regard, it is worthy to make a point on the essence of the concept of "administrative proceedings". According to I.M.Galiy, "administrative court proceedings are the process of considering administrative cases by courts in the manner established by the norms of administrative procedural legislation". [21] In our opinion, the scholar pays more attention to the general procedural aspects of the case.

E.S.Vasileva and V.K.Nekhaychik Administrative proceedings are primarily a fair trial, organized by specialized courts to protect the rights, freedoms and interests of citizens and legal entities, as well as to prevent arbitrariness of officials argues that it consists of dispute resolution [22].
The views of E.S. Vasileva and V.K. Nekhaychik are broader than those of I.M. Galiy, who called for the specialization of administrative courts in relation to other courts, the protection of those whose rights, freedoms and interests are violated by any actions of officials through the courts, and it also shows that the court is complying with the requirements of procedural law.

\section{CONCLUSION}

In our opinion, the conduct of administrative proceedings is not only the conduct of the case on the basis of procedural rules, but also the verification of compliance with administrative procedures in the course of the proceedings.

As well as, administrative proceedings are a stage of protection of violated or disputed rights, freedoms and legitimate interests of citizens and legal entities through administrative courts arising in the field of administrative and other public legal relations with administrative bodies. The task of conducting administrative court proceedings is assigned only in the administrative courts, which hear disputes related to public law relations.

\section{REFERENCES}

1. Luparev E.B. General theory of administrative and legal dispute. Voronezh, 2003.p. 11

2. Korkunov N.M. Russian state law. SPb., 1889.

3. Chechot D.M. Non claim production. M., 1973.p. 10. 
4. Khakhaleva E.V. Problems of delimiting public law and private law disputes. Theory and Practice of Social Development. (2010, No. 4) Art 196. https://cyberleninka.ru/article/n/problemy -razgranicheniya-publichno-pravovyh-ichastnopravovyh-sporov/viewer

5. Bolgova V.V.: Public law: problems of theory, methodology, practice. Author's abstract. Doctor of Science Law. - M. 2009.

6. Miyagasheva A.V. Concept and essence of public legal relations // Legal sciences. No. 9, 25.09.2017.

7. Nikolaenko V.: Problems of legal delimitation. // Issue No. 13 (431) dated 28.03.2006.

8. Shindyapin S. E. Subjects of public legal relations: problems of understanding and classification // Bulletin of the Tambov University. - 2014. - No. 6 (314). - p. 177182.

9. Bityak Yu.P., Bogutskiy V.V., Garashchuk V.M. / Administrative law of Ukraine is a contractor for legal university and faculties. Ed. Yu.P. Bityaka. - Kharkiv: Pravo, 2000 .-- P. 19.

10. Tikhomirov Yu. A. Public disputes // Law and Economics. 1998. No. 6. P. 8-13.

11. Nodirov, D. (2020). Issues of improving prosecutorial control over the implementation of legislation in the field of agriculture and food. European Journal of Molecular \& Clinical Medicine, 7(2), 663-670.

12. Peshkova TV Administrative proceedings in courts of general jurisdiction in the Russian Federation: dis. ... Cand. jurid. sciences. - Voronezh, 2014.p. 116
13. Starilov Yu.N. Administrative justice. Theory, history, perspectives. - M., 2001 .-p. 68

14. Glodina A.V. Administrative case and administrative legal dispute: concept and relationship // Administrative legal proceedings. 2017.No. 3 - P. 141-147.

15. Marchuk L. Administrative dispute: concept and debatable problems of definition / Visegrad Journal on Human Rights. 2016.5/2. - S. 91-96

16. Hamaneva N. Yu. Administrative and legal disputes: problems and methods of their resolution // State and law. 2006. No. 11. P. 5-13

17. . Nodirov, D. (2020). ENSURING THE SUPREMACY OF LAW IN THE DEVELOPMENT OF AGRICULTURE IN UZBEKISTAN. European Journal of Molecular \& Clinical Medicine, 7(8), 14141418.

18. Luparev E.B. Administrative and legal disputes: dis. ... doc. jurid. sciences. Voronezh, 2003. p. 14-15

19. Alekhin A.P., Karmolitskiy A.A., Kozlov Yu.M. Administrative law of the Russian Federation. Textbook. - M., Zertsalo, 1996.p. 309

20. Khojiev E.T., Xakimov G'.T. Administrative law. Study guide. Responsible editor: M.H.Rustamboev. - T .: Publishing House TSLU, 2011. P.293

21. Galiy I.M. On the question of the conceptual foundations of administrative justice // Russian judge. 2007. No. 1. P. 42.

22. Vasilyeva E.S., Nekhaychik V.K. The concept of administrative proceedings in the mechanism of administrative and legal impact // Administrative and municipal law. 2011. No. 10. P. 38 - 39. 
Doi: https://doi.org/10.37547/tajpslc/Volume03Issue02-05

23. Keeper N. G. Administrative and legal dispute (theoretical problems) // Legal world. 2007. No. 12. P.59-61

24. Nodirov, D. (2020). Issues of improving prosecutorial control over the implementation of legislation in the field of agriculture and food. European Journal of Molecular \& Clinical Medicine, 7(2), 663-670.

25. Ikromovich, N. D. (2020). The legal basis for assigning responsibilities to the prosecutor's office in ensuring control over the implementation of legislation in the agricultural sector in Uzbekistan. ACADEMICIA: AN INTERNATIONAL MULTIDISCIPLINARY RESEARCH JOURNAL, 10(12), 1058-1064.

26. Zamyshlyaev D.M. Types of court jurisdictions in the Russian Federation: comparative legal and historical approach: dissertation for Cand. jurid. sciences. - M., 2015.p. 100-101 